\title{
Pengaruh Pemberian Pembenah Tanah Terhadap Sifat Kimia Tanah Rizosfer Tanaman Kangkung
}

The Effect of Soil Amandement on the Chemical Properties of the Rizosfer on Kangkung

\author{
Rahmi Mulyana $^{1}$, Yusnizar ${ }^{1}$, Zainabun $^{1 *}$ \\ ${ }^{1}$ Program Studi Ilmu Tanah, Fakultas Pertanian, Universitas Syiah Kuala \\ *Corresponding author: zainabun@unsyiah.ac.id
}

\begin{abstract}
Abstrak. Kangkung darat (Ipomea reptans Poir) merupakan salah satu jenis sayuran yang sangat populer bagi rakyat Indonesia dan digemari oleh semua lapisan masyarakat. Tanaman kangkung termasuk kelompok tanaman sayuran semusim, berumur pendek dan tidak memerlukan areal yang luas untuk membudidayakannya, sehingga memungkinkan untuk dibudidayakan pada daerah perkotaan yang umumnya mempunyai lahan pekarangan terbatas. Penggunaan pembenah tanah utamanya ditujukan untuk memperbaiki kualitas sifat fisik, kimia dan biologi tanah, sehigga produktivitas tanah menjadi optimum. Penelitian ini bertujuan untuk mengetahui pengaruh pemberian pembenah tanah terhadap sifat kimia tanah di rizosfer pada tanaman kangkung. Rancangan percobaan yang digunakan dalam penelitian ini adalah Rancangan Acak Kelompok (RAK) Non Faktorial dengan 21 perlakuan dan tiga kali ulangan. Jenis pembenah tanah yang digunakan yaitu sekam padi, biochar sekam padi dan kotoran sapi. Hasil penelitian ini menunjukkan bahwa perlakuan pembenah tanah tidak berpengaruh nyata terhadap pH- $\mathrm{H}_{2} \mathrm{O}$; C-organik; N-total; C/N; K-dd; Na-dd; P-tersedia; KTK; dan DHL. Akan tetapi jika dilihat dari kiteria sifat kimia tanah secara umum masih dalam kriteria yang sama. Sifat kimia tanah yang diamati setelah perlakuan termasuk kriteria yang sama yaitu sifat kimia tanah : C-organik, P-tersedia, KTK dan DHL. Sifat kimia tanah yang diamati setelah perlakuan termasuk kriteria yang tidak sama yaitu sifat kimia tanah : $\mathrm{pH}$ tanah, N-total, rasio C/N, K-dd dan Na-dd.
\end{abstract}

Kata kunci : Pembenah tanah, Sifat Kimia Tanah, Kangkung, Pupuk Kandang

\begin{abstract}
Kangkung (Ipomea reptans Poir) is one type of vegetable that is very populer for the people of Indonesia and is loved ball levels. Kangkung include a seasonal vegetable group, are short live, and do not require large areas to cultivate them, so that posssible to be cultivated in urban areas which generally have limited land. The use of soil amandement is primarily intended to improve the quality of the physical, chemical biological properties of the soil, so that productivity to be optimum. This study aims to determine the effect of soil amandement on the chemical properties of the rhizosfer on Kangkung. The design used in this study was a randomized block design non factorial (RAK) with twentyone treatment and three replication. The type of soil amandement used are rice husk, biochar rice husk, and cow manure. The result of this study indicate that the treatment of sol amandement has no significant effect on $\mathrm{pH}-\mathrm{H}_{2} \mathrm{O}$; Organic-c; Total-N; C/N ratio; K-exchange; Na-exchange, available-P; cation exchange capacity; and electrical conductivity. However, when viewed from the criteria of soil chemistry in general it is still in the same criteria. Soil chemical properties observed after treatment include the same criteria namely soil chemical properties : Organic-c; available-P; cation exchange capacity; and electrical conductivity. Soil chemical properties observed after treatment include unequal criteria namely soil chemical properties : $\mathrm{pH}-\mathrm{H}_{2} \mathrm{O}$; total-n; $\mathrm{C} / \mathrm{N}$ ratio; K-exchange; and Na-exchange.
\end{abstract}

Keywords: Soil Amandement, Chemical Properties, Kangkung, Cow Manure

\section{PENDAHULUAN}

Kangkung termasuk jenis tanaman dengan kemampuan tumbuh cepat. Kangkung yang dikenal dengan nama latin Ipomoea reptans terdiri dari 2 (dua) varietas, yaitu kangkung darat yang disebut kangkung cina dan kangkung air yang tumbuh secara alami di sawah, rawa atau parit-parit. Tanaman kangkung termasuk kelompok tanaman sayuran semusim dan berumur pendek (Rukmana, 1994).

Pembenah tanah yang digunakan dalam penelitian ini ada beberapa acam yaitu, sekam padi, biochar sekam padi, dan pupuk kandang. Pemberian sekam padi pada tanah berperan penting dalam perbaikan struktur tanah sehingga sistem aerasi dan drainase di media tanam menjadi lebih baik. Sifat dari sekam padi mudah mengika air, tidak mudah lapuk, dan merupakan sumber kalium yang dibutuhkan tanaman. 
Biochar merupakan bahan kaya karbon yang berasal dari biomassa seperti kayu maupun sisa hasil pengolahan tanaman (Lehmann dan Joseps, 2009). Biochar dapat meningkatkan kualitas tanah dan digunakan sebagai salah satu alternatif untuk pembenah tanah. Keuntungan lain dari biochar adalah bahwa karbon pada biochar bersifat stabil dan dapat tersimpan selama ribuan tahun di dalam tanah (Gani, 2009).

Pupuk kandang merupakan sumber unsur hara bagi tanaman, macam-macam pupuk kandang yang sering digunakan adalah kotoran kuda, sapi, kerbau, kambing, ayam dan lainlain. Selain mengandung unsur hara, pupuk kandang juga membantu dalam penyimpanan air, terutama pada saat musim kemarau (Musnawar, 2003).

Berdasarkan permasalahan tersebut, maka perlu dilakukan penelitian untuk mengetahui pengaruh pemberian pembenah tanah terhadap sifat kimia tanah rizosfer tanaman kangkung.

\section{METODE PENELITIAN}

Penelitian dilaksanakan di Australian Center of International Agricultural Research (ACIAR) Experimental Site Campus, Universitas Syiah Kuala, Banda Aceh dan analisis dilaksanakan di Laboratorium Penelitian Tanah dan Tanaman Fakultas Pertanian Universitas Syiah Kuala. Penelitian dilaksanakan pada bulan November 2017 sampai April 2018.

Alat yang digunakan adalah bor tanah, cangkul, meteran, pisau, kantong plastik, tali plastik, gembor, termometer, dan peralatan pada saat analisis di Laboratorium. bahan yang digunakan antara lain benih kangkung darat varietas Bika, pupuk NPK, sekam padi, biochar sekam padi, pupuk kandang, air, dan sejumlah bahan kimia lainnya untuk analisis di Laboratorium.

Rancangan percobaan yang digunakan dalam penelitian ini adalah Rancangan Acak Kelompok (RAK) Non Faktorial dengan 21 perlakuan dan 3 kelompok.

\section{Pelaksanaan Kegiatan Penelitian}

\section{MATERI DAN METODE}

\section{Persiapan Lahan}

Tanah diolah menggunakan traktor dan cangkul. Pengolahan pertama menggunakan traktor dan pengolahan kedua menggunakan cangkul, tanah dicangkul dengan kedalaman 20 $\mathrm{cm}$, dan dibuat bedeng dengan ukuran $2 \times 2$ meter.

\section{Pengambilan Sampel Tanah untuk Analisis Awal}

Sampel tanah diambil pada masing-masing kelompok yaitu kelompok 1, 2, dan 3 kedalaman berkisar antara 0-20 cm, diambil dengan menggunakan bor tanah, masing kelompok diambil lima tempat dan dikompositkan menjadi satu sampel tanah. adapun aspek analisis awal dapat dilihat pada Tabel 1.

\section{Aplikasi Pembenah Tanah Organik}

Pembenah tanah diberikan dalam jangka waktu dua minggu sebelum penanaman, dan diaplikasikan sesuai dengan perlakuan. Pembenah tanah diberikan secara larikan ditempat penanaman tanaman kangkung, kemudian ditutup dan diinkubasi selama 2 minggu agar tanah bereaksi dengan pembenah tanah. Kemudian dilanjutkan ke tahap penanaman. 
Tabel 1. Aspek Analisis Awal Sifat Kimia Tanah

\begin{tabular}{|c|c|c|c|}
\hline No & Aspek Analisis & Satuan & Metode \\
\hline 1 & $\mathrm{pH}-\mathrm{H}_{2} \mathrm{O}$ & & Elektrometrik \\
\hline 2 & C-Organik & $\%$ & Walkey \& Black \\
\hline 3 & N-Total & $\%$ & Kjeldahl \\
\hline 4 & $\mathrm{C} / \mathrm{N}$ & & \\
\hline 5 & K-dapat ditukar & $\mathrm{cmol} \mathrm{kg}^{-1}$ & $1 \mathrm{NCOOCH}_{3} \mathrm{pH} 7$ \\
\hline 6 & Na-dapat ditukar & $\mathrm{cmol} \mathrm{kg}^{-1}$ & $1 \mathrm{NCOOCH}_{3} \mathrm{pH} 7$ \\
\hline 7 & P-tersedia & $\mathrm{mg} \mathrm{kg}^{-1}$ & Bray II \\
\hline 8 & KTK (Kapasitas Tukar kation) & $\mathrm{cmol} \mathrm{kg}^{-1}$ & $1 \mathrm{NCOOCH}_{3} \mathrm{pH} 7$ \\
\hline 9 & DHL (Daya Hantar Listrik) & $\mathrm{ds} / \mathrm{m}$ & Elektrometrik \\
\hline 10 & $\mathrm{Fe}$ (terekstrak) & ppm & $1 \mathrm{~N} \mathrm{NH}_{4} \mathrm{OAc} \mathrm{pH} 4,8$ \\
\hline
\end{tabular}

Sumber : Laboratorium Penelitian Tanah dan Tanaman, 2017.

\section{Penanaman dan Aplikasi Pembenah Tanah Anorganik (pupuk buatan)}

Jarak tanam pada tanaman kangkung adalah $10 \mathrm{~cm}$ x $20 \mathrm{~cm}$. Penanaman dilakukan secara tugal dengan kedalaman $2 \mathrm{~cm}$ dan setiap lubang tanam ditanami 3 benih kangkung. Pupuk yang diberikan saat tanam juga sebagai pembenah tanah adalah pupuk Urea, $\mathrm{KCl}$, dan NPK sesuai perlakuan.

\section{Pemeliharaan Tanaman}

Pemeliharaan tanaman kangkung meliputi penyiraman, penyulaman, penyiangan, dan pembumbunan. Penyiraman dilakukan setiap pagi dan sore hari dan disesuaikan sesuai dengan kondisi cuaca. Penyulaman dilakukan pada tanaman berumur satu minggu setelah tanam.

\section{Pengambilan Sampel Akhir}

Pemanenan dilakukan pada saat tanaman berumur 30 hari setelah tanam (HST). Pengambilan sampel tanah diambil sekitar perakaran tanaman untuk dianalisis di laboratorium. Sampel tanah diambil 20 titik dalam satu bedeng dengan menggunakan ubinan berukuran $1 \mathrm{~m}$ x $1 \mathrm{~m}$, kemudian dikompositkan menjadi satu sampel tanah. 


\section{HASIL DAN PEMBAHASAN}

\section{Hasil Analisis Tanah Awal}

Tabel 2. Hasil Analisis Awal Sifat Kimia Tanah

\begin{tabular}{|c|c|c|c|c|c|}
\hline No. & Aspek Analisis & Satuan & Metode & Nilai & Kriteria \\
\hline 1 & $\mathrm{pH}-\mathrm{H}_{2} \mathrm{O}$ & & Elektrometrik & 6,84 & netral \\
\hline 2 & C-Organik & $\%$ & Walkex \& Black & 0,42 & sangat rendah \\
\hline 3 & N-Total & $\%$ & Kjeldahl & 0,07 & sangat rendah \\
\hline 4 & $\mathrm{C} / \mathrm{N}$ & $\%$ & & 6 & rendah \\
\hline 5 & K-dapat ditukar & $\mathrm{smol} \mathrm{kg-1}^{-1}$ & $1 \mathrm{NNH}_{4} \mathrm{COOCH}_{3} \mathrm{pH} 7$ & 0,36 & rendah \\
\hline 6 & Na-dapat ditukar & $\mathrm{cmolkg}^{-1}$ & $1 \mathrm{NNH}_{4} \mathrm{COOCH}_{3} \mathrm{pH} 7$ & 0,11 & rendah \\
\hline 7 & P-tersedia & $\mathrm{mgkg}^{-1}$ & Bray II & 71,9 & sangat tinggi \\
\hline 8 & $\begin{array}{l}\text { KTK (Kapasitas } \\
\text { Tukar Kation) }\end{array}$ & $\mathrm{cmolkg}^{-1}$ & $1 \mathrm{NNH}_{4} \mathrm{COOCH}_{3} \mathrm{pH} 7$ & 15,6 & rendah \\
\hline 9 & $\begin{array}{l}\text { DHL (Daxa Hantar } \\
\text { Listrik) }\end{array}$ & $\mathrm{ds} / \mathrm{m}$ & Elektrometrik & 0,16 & sangat rendah \\
\hline 10 & $\mathrm{Fe}$ (terekstrak) & $\mathrm{Ppm}$ & $1 \mathrm{NNH}_{4} \mathrm{OAc} \mathrm{pH} 4,8$ & tu & sangat rendah \\
\hline
\end{tabular}

Sumber : Laboratorium Penelitian Tanah dan Tanaman, 2017.

\section{Hasil Analisis Akhir pH Tanah akibat Perlakuan}

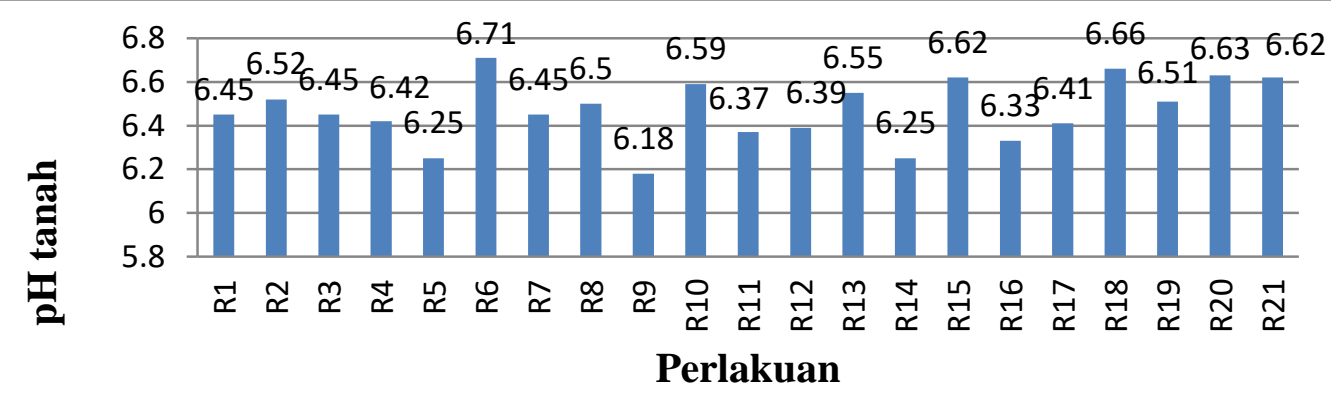

Gambar 1. Rata-rata nilai pH tanah akibat perlakuan

Hasil analisis ragam menunjukkan perlakuan pembenah tanah tidak berpengaruh nyata terhadap $\mathrm{pH}$ tanah. Hal ini disebabkan dosis yang diberikan pada semua perlakuan masih tergolong rendah terutama di pembenah tanah organik yaitu 2.5 ton/ha sampai 5 ton/ha. Hasil penelitian Nisa (2010) menunjukkan bahwa tanah yang diberi perlakuan biochar 10 ton/ha dapat menaikkan $\mathrm{pH}$ tanah dari 6,78 menjadi 7,40 atau naik $9,14 \%$.

\section{C-organik Tanah akibat Perlakuan}

Berdasarkan hasil analisis awal dan akhir maka terjadi perubahan nilai C-organik tanah walaupun kriteria sebelum perlakuan dan setelah perlakuan adalah sama yaitu sangat rendah. Nilai C-organik tanah awal sebelum perlakuan yaitu $0,42 \%$ dengan kriteria sangat rendah. Setelah perlakuan, adanya peningkatan nilai C-organik tanah. C-organik setelah perlakuan berkisar antara 0,58-0,81\%. 


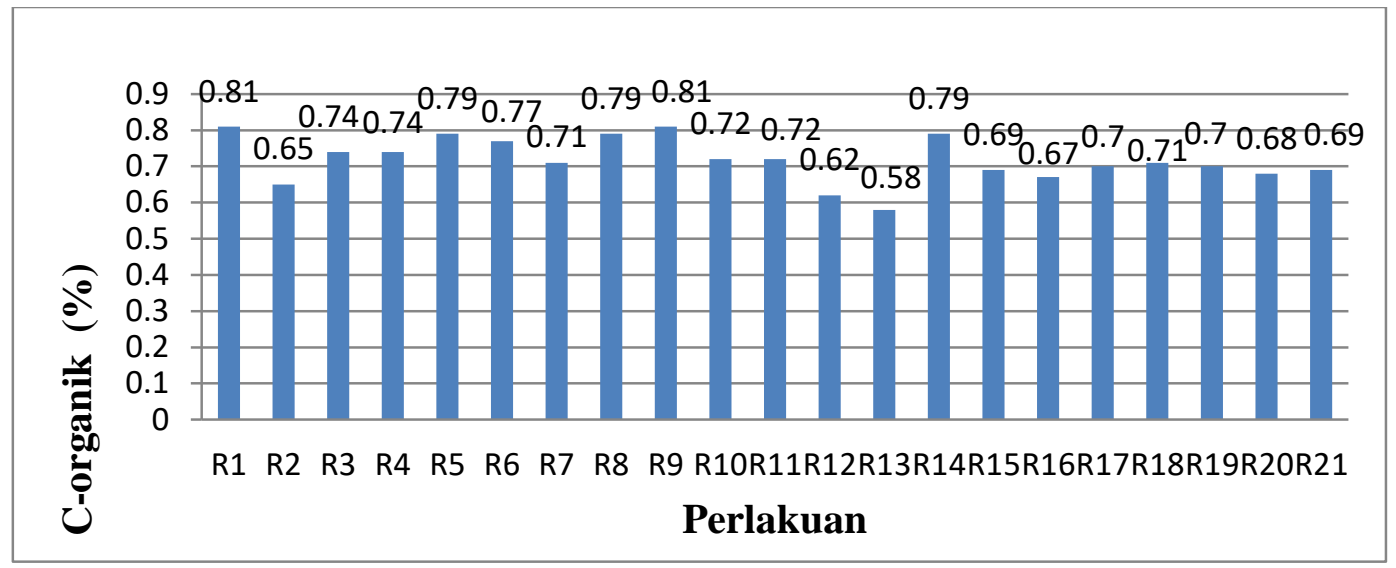

Gambar 1. Rata-rata nilai C-organik tanah akibat perlakuan

Hasil analisis ragam menunjukkan bahwa pembenah tanah tidak berpengaruh nyata terhadap C-organik. Menurut (Steiner et al., 2007 dalam Mawardiana et al., 2013) biochar sebagai bahan pembenah tanah memiliki sifat rekalsitran, lebih tahan terhadap oksidasi dan lebih stabil dalam tanah sehingga memiliki pengaruh jangka panjang terhadap perbaikan kualitas kesuburan tanah (C-organik tanah dan KTK). Nurida et al. (2012) menyatakan bahwa biochar sekam padi memiliki kandungan C-organik > 35\%. Selain itu, keuntungan jangka panjang yang diperoleh dengan pemberian biochar bagi ketersediaan hara berhubungan dengan stabilisasi karbon organik yang lebih tinggi seiring dengan pembebasan hara yang lebih lambat dibandingkan dengan bahan organik yang biasa digunakan.

\section{N-total Tanah akibat Perlakuan}

Dengan adanya perlakuan ada terjadi perubahan terhadap nilai $\mathrm{N}$-total. Nilai $\mathrm{N}$-total awal sebelum perlakuan yaitu 0,07 dengan kriteria sangat rendah. Setelah perlakuan, adanya peningkatan nilai $\mathrm{N}$-total. Nilai N-total setelah perlakuan berkisar antara 0,06-0,08.

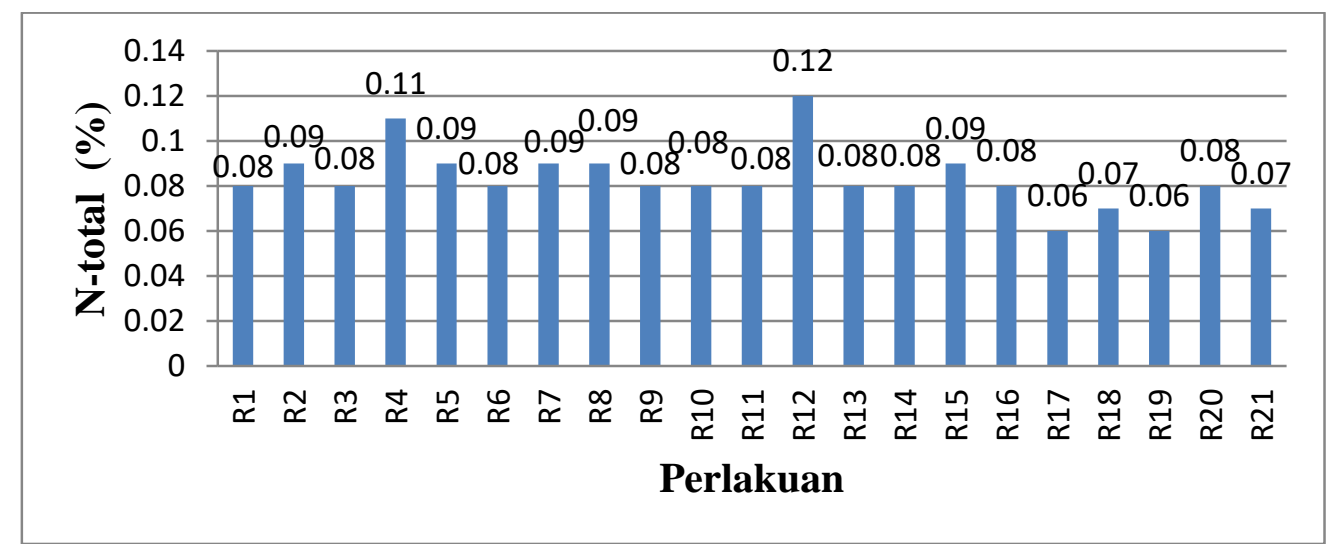

Gambar 3. Rata-rata nilai N-total tanah akibat perlakuan

Dari semua perlakuan yang dicobakan, perlakuan $\left(\mathrm{R}_{12}\right)$ yang dapat meningkatkan nilai $\mathrm{N}$-total dan merubah kriteria $\mathrm{N}$-total dari kriteria sangat rendah menjadi kriteria rendah. Hasil analisis ragam menunjukkan bahwa pemberian pembenah tanah tidak berpengaruh nyata terhadap N-total tanah. Rendahnya kandungan N-total tanah dapat terjadi karena telah diserap oleh tanaman, menguap atau tercuci. Hal ini sesuai dengan pendapat Muklis dan Fauzi (2003) dalam Nariratih et al., (2013) yaang menyatakan bahwa ketidaktersediaan $\mathrm{N}$ dalam tanah 
dapat terjadi karena adanya proses pencucian $\mathrm{NO}_{3}{ }^{-}$, denitrifikasi $\mathrm{NO}_{3}{ }^{-}$, menjadi $\mathrm{N}_{2}$, volatilisasi $\mathrm{NH}_{4}{ }^{+}$menjadi $\mathrm{NH}_{3}{ }^{-}$, terfiksasi oleh mineral liat atau dikonsumsi oleh mikroorganisme tanah.

\section{Rasio C/N Tanah akibat Perlakuan}

Nilai rasio $\mathrm{C} / \mathrm{N}$ tanah awal sebelum perlakuan yaitu 6 dengan kriteria rendah. Setelah perlakuan, adanya dan peningkatan nilai rasio $\mathrm{C} / \mathrm{N}$ tanah. Nilai rasio $\mathrm{C} / \mathrm{N}$ tanah setelah perlakuan berkisar antara 11,3-9,25. Nilai rasio $\mathrm{C} / \mathrm{N}$, dapat dilihat bahwa telah terjadi peningkatan $\mathrm{C} / \mathrm{N}$ akibat adanya perlakuan yang dicobakan yaitu dari 6 menjadi 3,05 atau peningkatan nilai $\mathrm{N}$-total sebesar 2,95. Rata-rata nilai rasio $\mathrm{C} / \mathrm{N}$ tanah akibat perlakuan dapat dilihat pada Gambar 4 dibawah ini.

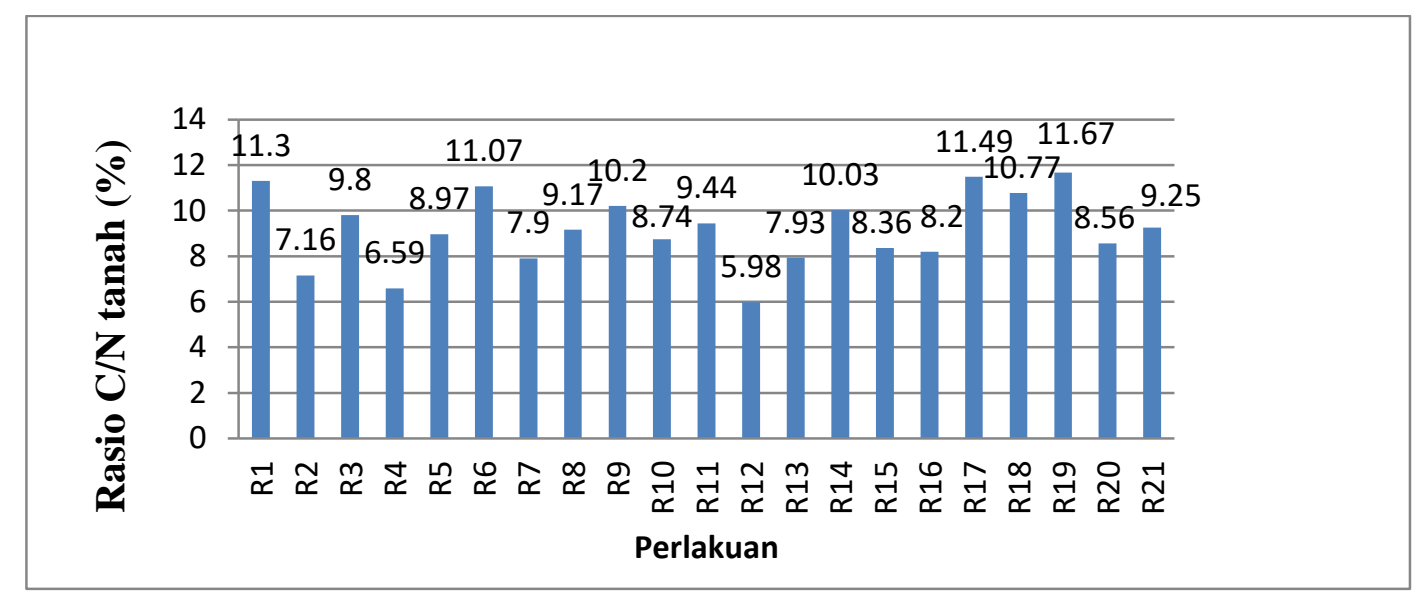

Gambar 4. Rata-rata nilai rasio $\mathrm{C} / \mathrm{N}$ tanah akibat perlakuan

Hasil analisis ragam menunjukkan bahwa pemberian pembenah tanah tidak berpengaruh nyata terhadap rasio $\mathrm{C} / \mathrm{N}$ tanah. Hal ini diduga bahwa pemberian bahan organik memberikan kontribusi baik dalam menyeimbangkan rasio $\mathrm{C} / \mathrm{N}$ bahan organik dengan tanah, dimana perbandingan antara $\mathrm{C}$ dengan $\mathrm{N}$ mempengaruhi proses mineralisasi dan imobillisasi, seperti yang dinyatakan dalam literatur Djuarnani et al., 2005 dalam Nariratih et al., 2005) bahwa prinsip pengomposan adalah menurunkan nilai nisbah $\mathrm{C} / \mathrm{N}$ bahan organik menjadi sama dengan nisbah rasio $\mathrm{C} / \mathrm{N}$ tanah.

\section{K-dd (dapat ditukar) Tanah akibat Perlakuan}

Nilai K-dd awal sebelum perlakuan yaitu 0,36 dengan kriteria rendah. Setelah perlakuan, adanya peningkatan nilai K-dd. Nilai K-dd setelah perlakuan berkisar antara 0,44-0,82. terjadi penurunan K-dd akibat adanya perlakuan yang dicobakan yaitu dari 0,36 menjadi 0,59 atau penurunan nilai K-dd tanah sebesar 0,16. Rata-rata nilai K-dd tanah akibat perlakuan dapat dilihat pada Gambar 5 dibawah ini. 


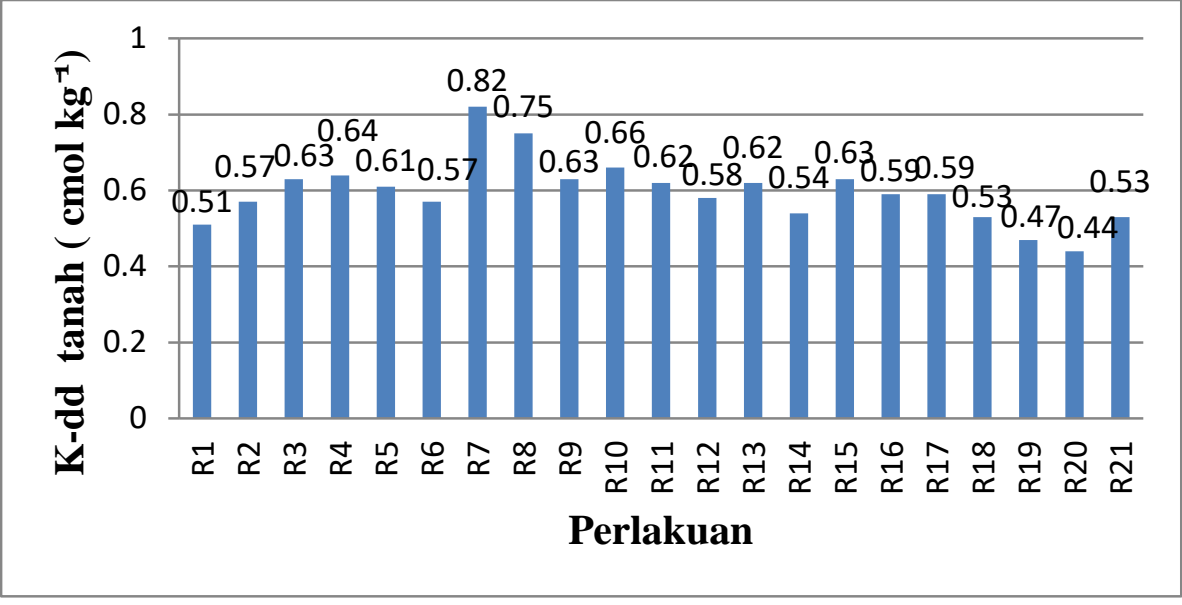

Gambar 5. Rata-rata nilai K-dd tanah akibat perlakuan

Pemberian pembenah tanah telah memberikan pengaruh terhadap K-dd. Dari perlakuan diatas dapat kita lihat bahwa perlakuan sekam padi 2,5 ton/ha $\left(\mathrm{R}_{7}\right)$ menunjukkan perubahan K-dd yang lebih tinggi dibandingkan dengan perlakuan lainnya. Sedangkan perlakuan kotoran sapi 5 ton/ha $\left(\mathrm{R}_{20}\right)$ memiliki nilai sangat rendah dibandingkan dengan perlakuan lainnya dengan nilai $\mathrm{K}$ dd sebesar 0,44 hanya dapat meningkatkan 0,08 dari sebelum perlakuan.

\section{Na-dd (dapat ditukar) Tanah akibat Perlakuan}

Nilai Na-dd awal sebelum perlakuan yaitu 0,11 dengan kriteria rendah. Setelah perlakuan, adanya peningkatan nilai Na-dd. Nilai Na-dd setelah perlakuan berkisar antara $0,09-0,27$. Terjadi penurunan Na-dd tanah akibat adanya perlakuan yang dicobakan yaitu dari 0,11 menjadi 0,06 atau penurunan nilai Na-dd sebesar 0,05. Rata-rata nilai Na-dd tanah akibat perlakuan dapat dilihat pada Gambar 6.

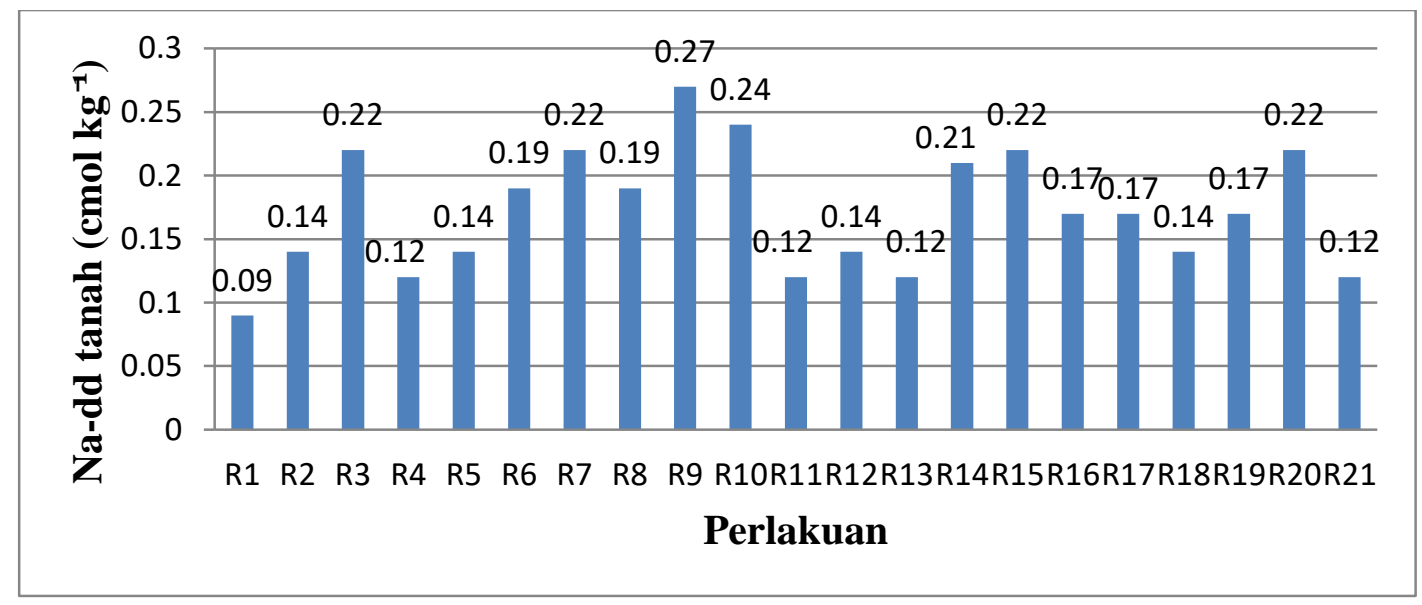

Gambar 6. Rata-rata nilai Na-dd tanah akibat perlakuan

Pemberian pembenah tanah telah memberikan pengaruh terhadap Na-dd. Dari keterangan diatas dapat kita lihat bahwa pemberian sekam padi 5 ton/ha + NPK $50 \%\left(\mathrm{R}_{9}\right)$ menunjukkan perubahan K-dd yang lebih tinggi dibandingkan dengan perlakuan lainnya yaitu meningkat sebesar 0,16 . Sedangkan tanpa perlakuan $\left(R_{1}\right)$ memiliki nilai sangat rendah 
dibandingkan dengan adanya perlakuan lainnya yaitu memiliki nilai Na-dd sebesar 0,09 atau telah terjadi penuruan nilai Na-dd sebesar 0,02 dari sebelum perlakuan.

\section{P-tersedia Tanah akibat Perlakuan}

Nilai P-tersedia awal sebelum perlakuan yaitu 71,9 ppm dengan kriteria sangat tinggi. Setelah perlakuan, adanya penurunan nilai P-tersedia. Nilai P-tersedia setelah perlakuan berkisar antara 29,06-40,82. telah terjadi penurunan dari hasil analisis awal sebesar dari 71,9 ppm menjadi $11,54 \mathrm{ppm}$ atau penurunan nilai P-tersedia. sebesar 60,36. Rata-rata nilai Ptersedia tanah akibat perlakuan dapat dilihat pada Gambar 7.

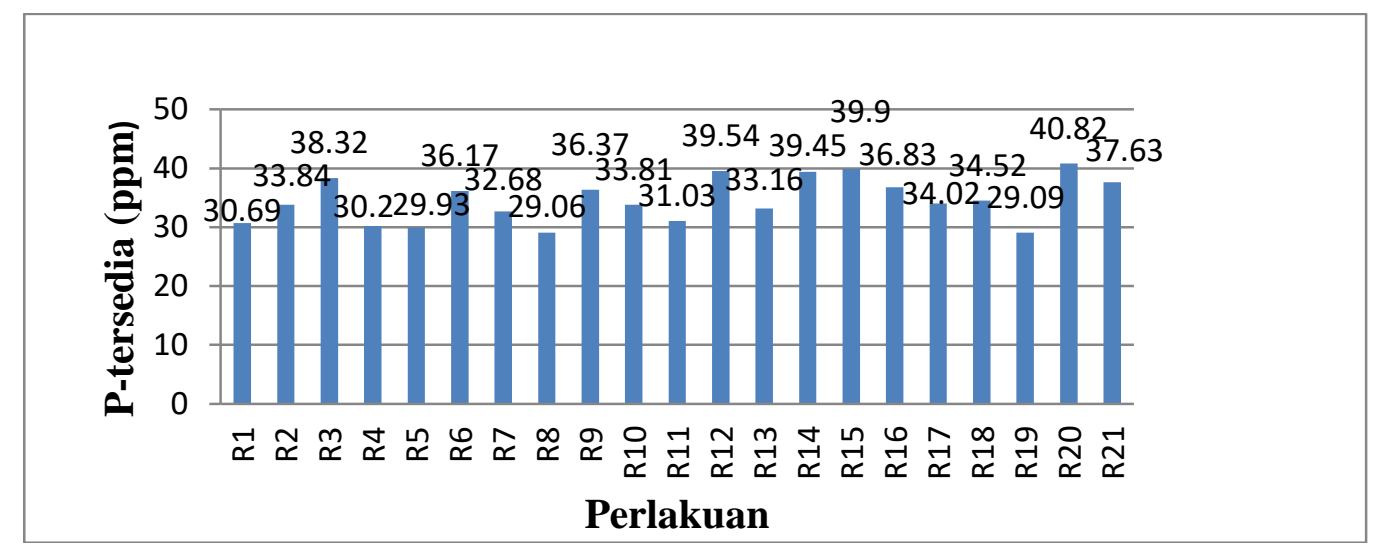

Gambar 7. Rata-rata nilai P-tersedia tanah akibat perlakuan

Hasil analisis ragam menunjukkan bahwa pemberian pembenah tanah tidak berpengaruh nyata terhadap P-tersedia. Hal ini diduga karena dosis yang diberikan masih rendah dan waktu yang terlalu singkat. Hal ini sesuai dengan hasil penelitian (Salawati et al., 2016) menunjukkan bahwa pemberian biochar 15 ton/ha dengan kehalusan 60 mesh dapat meningkatan P-tersedia hingga 277,08\%.

\section{KTK Tanah akibat Perlakuan}

Nilai KTK awal sebelum perlakuan yaitu $15,6\left(\mathrm{cmol} \mathrm{kg}^{-1}\right)$ dengan kriteria rendah. Setelah perlakuan, adanya penurunan nilai KTK berkisar antara 6,00-10,00 dengan nilai KTK rata-rata umum sebesar $2,50\left(\mathrm{cmol} \mathrm{kg}^{-1}\right)$. Terjadi penurunan $\mathrm{K}$-dd akibat adanya perlakuan yang dicobakan yaitu dari $15,6\left(\mathrm{cmol} \mathrm{kg}^{-1}\right)$ menjadi $2,50\left(\mathrm{cmol} \mathrm{kg}^{-1}\right)$ atau peurunan nilai KTK sebesar 13,1. Rata-rata nilai KTK tanah akibat perlakuan dapat dilihat pada Gambar 8.

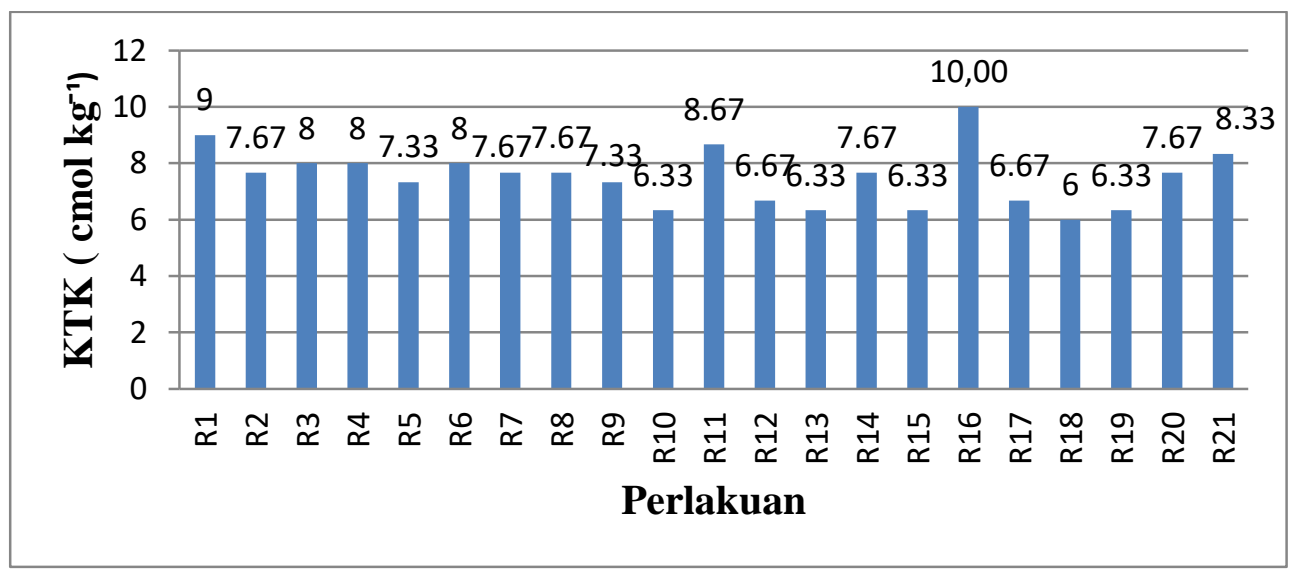

Gambar 8. Rata-rata nilai KTK tanah akibat perlakuan 
Hasil analisis ragam menunjukkan bahwa pemberian pembenah tanah tidak berpengaruh nyata terhadap KTK. Menurut Gani, 2010, penambahan biochar ke tanah meningkatkan ketersediaan kation utama dan fosfor, total $\mathrm{N}$ dan kapasitas tukar kation tanah (KTK) yang pada akhirya meningkatkan hasil, Peran biochar terhadap peningkatan produktivitas tanaman dipengaruhi oleh jumlah yang ditambahkan.

\section{DHL (Daya Hantar Listrik) Tanah akibat Perlakuan}

Nilai DHL awal sebelum perlakuan yaitu $0,16\left(\mathrm{mS} \mathrm{cm}^{-1}\right)$ dengan kriteria sangat rendah. Setelah perlakuan, adanya penurunan nilai DHL berkisar antara 0,06-0,09. penurunan DHL akibat adanya perlakuan yang dicobakan yaitu dari $0,16\left(\mathrm{mS} \mathrm{cm}^{-1}\right)$ menjadi $0,02(\mathrm{mS}$ $\mathrm{cm}^{-1}$ ) atau penurunan nilai DHL sebesar 0,14 . Rata-rata nilai DHL tanah akibat perlakuan dapat dilihat pada Gambar 9.

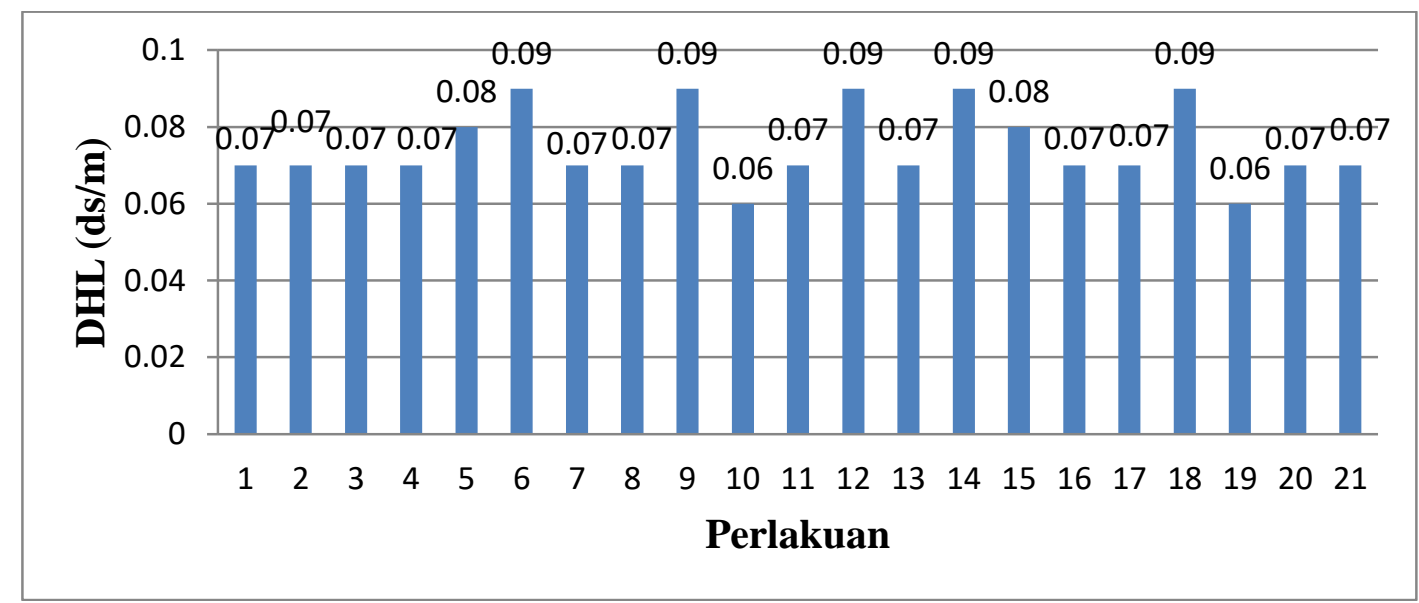

Gambar 9. Rata-rata nilai DHL tanah akibat perlakuan

Hasil analisis ragam menunjukkan bahwa pemberian pembenah tanah tidak berpengaruh nyata terhadap DHL. Nilai daya hantar listrik sebelum dan sesudah perlakuan tidak ada terjadi peningkatan di semua perlakuan. Jika konsentrasi garam meningkat, maka kemampuan larutan menghantarkan listrik akan meningkat.

\section{KESIMPULAN DAN SARAN}

\section{KESIMPULAN}

Perlakuan pembenah tanah tidak berpengaruh nyata terhadap $\mathrm{pH}-\mathrm{H}_{2} \mathrm{O}$; C-organik; Ntotal; C/N; K-dd; Na-dd; P-tersedia; KTK; dan DHL. Akan tetapi jika dilihat dari kiteria sifat kimia tanah secara umum masih dalam kriteria yang sama. Sifat kimia tanah yang diamati setelah perlakuan termasuk kriteria yang sama yaitu sifat kimia tanah : C-organik, P-tersedia, KTK dan DHL. Sifat kimia tanah yang diamati setelah perlakuan termasuk kriteria yang tidak sama yaitu sifat kimia tanah : pH tanah, N-total, rasio C/N, K-dd dan Na-dd.

\section{SARAN}

Dibutuhkan penelitian lebih lanjut dengan waktu yang lebih lama untuk mengetahui efek residu dari perlakuan pembenah tanah yang digunakan pada penelitian ini. 


\section{DAFTAR PUSTAKA}

Gani, A. 2009. Biochar penyelamat lingkungan. Warta penelitian dan pengembangan pertanian. 3 (6). 2010. Multiguna arang hayati biochar. Sinar Tani.

Rukmana, R. 1994. Bertanam kangkung. Kanisius. Yogyakarta.

Lehman dan Josep. 2009. Biochar for environmental management: Science and Technology. Earthscan-UK.

Mawardiana, Sufardi dan E. Husen. 2013. Pengaruh residu biochar dan pemupukan NPK terhadap sifat kimia tanah dan pertumbuhan serta hasil tanaman padi musim ketiga. Magister Konservasi Sumberdaya Lahan Pasca Sarjana Universitas Syiah kuala. Banda Aceh.1(1).

Musnamar, E. I. 2003. Pupuk Organik. Penebar Swadaya. Jakarta.

Nariratih, I. Damanik, G. Sitanggang. 2013. Ketersediaan nitrogen pada tiga jenis tanah akibat pemberian bahan organik dan serapannya pada tanaman jagung. Jurnal Online Agroekoteknologi. 1(3).

Nisa, K. 2010. Pengaruh pemupukan NPK dan biochar terhadap sifat kimia tanah, serapan hara dan hasil tanaman padi sawah. Thesis. Banda Aceh. Universitas Syiah Kuala.

Nurida, N.L, Rachman, A dan Sutono. 2012. Potensi pembenah tanah biochar dalam pemulihan sifat tanah terdegradasi dan peningkatan hasil jagung pada typic kanhapludults Lampung. Balai Penelitian Tanah, Bogor. Buana Sains. $12(1)$.

Salawati, M. Basri, L., Kadeoh, dan A.R. Thaha. 2016. Potensi biochar sekam padi terhadap perubahan $\mathrm{pH}$, KTK, C-organik, dan P-tersedia pada tanah sawah Inceptisol. Universitas Tadulako, Jurnal Agroland. 2 (3). 